\title{
Social Studies Learning With Visualization, Auditory, Kinesthetic (VAK) Learning Model Assisted by Diorama Media Increases Student Knowledge Competence
}

\author{
Ni Luh Komang Widya Santhi' ${ }^{1}$, I. G. A. Agung Sri Asri² ${ }^{2}$ I.B. Surya Manuaba ${ }^{3}$ \\ ${ }^{123}$ Program Studi Pendidikan Guru Sekolah Dasar, Fakultas Ilmu Pendidikan, Universitas Pendidikan Ganesha, Bali, Indonesia
}

\begin{abstract}
ARTICLEINFO
kata kunci:

VAK, diorama, ips

keywords:

VAK, diorama, social

sciences \section{Article history: \\ Received 2 Juni 2020 \\ Received in revised form \\ 12 Juli 2020 \\ Accepted 10 Agustus 2020 \\ Available online 28 Agustus 2020}

A B S T R A K

Rendahnya kompetensi pengetahuan IPS siswa yang disebabkan oleh kurang optimalnya penggunaan model pembelajaran yang inovatif dan kreatif serta kurangnya penggunanan media pembelajaran. Penelitian ini memiliki tujuan yaitu untuk menganalisis pengaruh yang signifikan model pembelajaran visualization, auditory, kinestetic (VAK) berbantuan media diorama terhadap kompetensi pengetahuan IPS siswa SD. Penelitian ini merupakan penelitian kuantitatif dengan desain eksperimental yaitu quasi eksperimen (eksperimen semu) dengan rancangan penelitian non equivalent pretest posttest control group design. Populasi pada penelitian ini yaitu seluruh siswa kelas IV SD yang berjumlah 275 siswa. Penetapan sampel dengan menggunakan teknik random sampling yang kemudian diperoleh dua kelas. Kelas IV dengan jumlah 39 siswa dibelajarkan dengan model pembelajaran VAK berbantuan media diorama dan kelas IV dengan jumlah 37 siswa dibelajarkan dengan pembelajaran konvensional. Data dikumpulkan dengan tes pilihan ganda biasa kemudian dianalisis dengan uji t polled varians. Berdasarkan analisis uji t diperoleh thitung $=6,726$ dengan taraf signifikansi $5 \%$ dan $\mathrm{dk} 39+37-2=74$ diperoleh $t_{\text {tabel }}=1,993$. Berdasarkan kriteria pengujian thitung $=6,726>t_{\text {tabel }}=1,993$. Jadi dapat disimpulkan bahwa terdapat pengaruh yang signifikan model pembelajaran visualization, auditory, kinestetic (VAK) berbantuan media diorama terhadap kompetensi pengetahuan IPS siswa kelas IV SD.
\end{abstract}

\begin{abstract}
A B S T R A C T
The low students' competency of IPS (social science) is caused by the not optimal application of creative and innovative learning models and lack of learning media use. This research is aimed to analyze the impact of visualization, auditory, kinesthetic (VAK) learning model assisted with a diorama on social studies competency of elementary school students. It is quantitative research with the experimental design of quasi-experiment and non-equivalent pretest-posttest control group design. The population in this research are 275 grade IV students. Samples were taken with a random sampling technique, resulted in two classes. Class IV numbering 39 students were treated with VAK learning model assisted with diorama, and class IV numbering 37 students treated with conventional teaching and learning. Data were obtained by a common multiple-choice test and were then analyzed using polled variants t-test. It resulted the $t$ count $=6,762$ at $5 \%$ significance level with $39+37-2=74$ and $t$ table $=1,993$. Based on test criteria $t$ count $=6,726>t$ table $=1,993$. It leads to a conclusion that there is a significant influence of the VAK learning model aided with diorama media on IPS competency of grade IV students.
\end{abstract}

\section{Introduction}

In facing an increasingly tough future, the nation's young generation must be well equipped. The preparation can be carried out by providing knowledge that is carried out at every level of education, especially when students are studying in elementary school. At the elementary school level, one of the things students must achieve is knowledge competency. Competency is an ability that must be achieved by students which includes three aspects. These aspects are attitude competency which includes spiritual attitudes and social attitudes, knowledge competency to reach knowledgeable people, and the last is skill competency to reach capable and creative people.

At the Elementary School level, IPS is one of the subjects integrated into the 2013 curriculum. According to (Pratiwi, 2014), IPS is a science that combines or includes various branches of science related to social knowledge ranging from history, sociology, geography, politics, economics, law. until the science of culture. Social studies is a subject matter that not only conveys knowledge alone, but

Corresponding author.

Copyright (C) Universitas Pendidikan Ganesha. All rights reserved.

idabagussurya.manuaba@undiksha.ac.id ${ }^{3}$ (Surya Manuaba) 
the young generation of Indonesians at the school level is very important to be equipped with social knowledge, social values, and social skills, besides being useful for everyday life as well as developing their potential.

The process of implementing learning during social studies learning, the teacher should be able to create a pleasant atmosphere so that students become more active. According to (Setiawan, 2019), student activeness in following the learning process is one of the keys to the success of learning objectives. Learning that takes place is only teacher-centered and there is a lack of innovation in using learning models. This is in line with (Alditia, 2016) which states that students are generally not allowed to find their answers, lack of curiosity about the material, low interest in learning which leads to student boredom and low student learning outcomes. The content of social studies material is learning that is more memorizing so that the learning that takes place becomes boring and students become passive. According to (Parbawa, 2018) IPS is a very important science in understanding culture, the environment, and the country itself. This can be seen when learning takes place students do not pay attention to the teacher when explaining the material and prefer to talk to friends around them or do things that have nothing to do with the content of social studies material.

Based on the results of observations and interviews conducted at Elementary School in Gugus Letda Kajeng on November 28, 2019, these problems also occurred, there were several problems in the implementation of learning. These problems are divided into two factors. (Purwandari, 2014) states that internal factors are problems that are present in students such as interest, intelligence to motivation. There are other things such as students lacking in interpreting the material, low participation, students lack of focus when implementing learning runs, students find it difficult to memorize material because the content of social studies is mostly memorization which makes students feel bored even though social studies is a very important science in understanding culture, environment and country. External factors are problems that come from the surrounding environment, both facilities and infrastructure, an atmosphere that is not conducive so that learning materials will not be fully conveyed to students. So that it affects the KKM that must be achieved by students.

Tabel 1. Middle-Term Exam Value for Social Studies Learning Content at Elementary School in Gugus Letda Kajeng.

\begin{tabular}{|c|c|c|c|c|c|c|}
\hline No & School Identity & Class & $\begin{array}{l}\text { Standard } \\
\text { Value }\end{array}$ & $\begin{array}{c}\text { Total } \\
\text { Student }\end{array}$ & $\begin{array}{c}\text { Total Student } \\
\text { under } \\
\text { Standard } \\
\text { Value }\end{array}$ & $\begin{array}{c}\text { Total } \\
\text { Student } \\
\text { above } \\
\text { Standard } \\
\text { Value } \\
\end{array}$ \\
\hline \multirow[t]{2}{*}{1} & $\begin{array}{l}\text { Elementary School of } \\
4 \text { Pemecutan }\end{array}$ & IV A & 70 & 40 & 25 & 15 \\
\hline & & IV B & 70 & 39 & 19 & 20 \\
\hline 2 & $\begin{array}{l}\text { Elementary School of } \\
8 \text { Pemecutan }\end{array}$ & IV A & 70 & 37 & 20 & 17 \\
\hline \multirow[t]{2}{*}{3} & $\begin{array}{l}\text { Elementary School of } \\
12 \text { Pemecutan }\end{array}$ & IV A & 70 & 24 & 15 & 9 \\
\hline & & IV B & 70 & 24 & 11 & 13 \\
\hline \multirow[t]{2}{*}{4} & $\begin{array}{l}\text { Elementary School of } \\
14 \text { Pemecutan }\end{array}$ & IV A & 70 & 30 & 17 & 13 \\
\hline & & IV B & 70 & 27 & 15 & 12 \\
\hline \multirow[t]{2}{*}{5} & $\begin{array}{l}\text { Elementary School of } \\
24 \text { Pemecutan }\end{array}$ & IV A & 70 & 31 & 16 & 15 \\
\hline & & IV B & 70 & 23 & 10 & 13 \\
\hline
\end{tabular}

The reason many students have not reached the Standard Value is that during the learning process the teacher uses the lecture method more often so that the delivery of material is only based on the teacher. Learning resources do not vary and only use handbooks. Such learning has an impact on the activeness and enthusiasm of students, so that students do not understand the material presented by the teacher. According to (Wahyuni, 2020) the delivery of information directly to students without being accompanied by the involvement of students as individuals who have initial 
knowledge that will be perfected by the teacher in learning activities does not make learning meaningful because teachers have an important role in exploring students' initial knowledge and combining it with knowledge. new so that students do not experience misconceptions about things that have been known before. When observation during observation, learning that takes place is more likely to conventional learning. (Agung, 2014) states that conventional learning in its application does not involve the activation of the initial knowledge possessed by students and does not motivate students. According to (Trianto, 2012), conventional learning activities have 8 characteristics: 1) In group division, the teacher allows students to lead the group so that when there are students who do not dominate the student, they will choose to remain silent. 2) The knowledge of each student will vary; it will affect the assignment. Students who have more abilities will make assignments given by the teacher by themselves, while other students will accept it because there are friends who will make it. 3) The division of groups tends to be more homogeneous so that there is jealousy between one group and another. 4) Group selection is often released to students so that students will choose a smart leader or group leader who is willing to do group assignments by themselves and other members are just waiting for the results. 5) Social skills are not taught directly. 6) When students are carrying out observations, the teacher does not carry out monitoring in stages. 7) The teacher does not pay attention to the processes experienced by the group. 8) In the process of implementing teacher learning, it emphasizes on task completion only.

Based on the problems that have been described, it is important to hold innovation in the implementation of learning both in terms of models and learning media so that students become enthusiastic about learning. According to (Sakti, 2019) the use of innovative learning models provides a framework and direction for teachers in designing learning. In this study, the Visualization, Auditory, Kinesthetic (VAK) Learning Model was tested. Meanwhile (Adnyani, 2014) argues that the VAK learning model is a model in learning that takes into account the three learning styles of children, visual, auditory, and finally kinesthetic (Nurellah, 2016). The VAK model assumes that the implementation of learning will be effective if the three learning styles are used. This model emphasizes students' abilities and makes the most of them, trains, and develops them. (Suryantini, 2017) argues that if students have a visual learning style (seeing), students will easily learn using two-dimensional media. Auditory (listening) students will learn easily by listening to the subject matter. While the kinesthetic learning style will easily learn with motion and emotion. According to (Sari, 2014) the characteristics of learning styles will affect the learning process, processing the information they get, and communication in conveying an opinion. (Elisa, 2019) argues that there are advantages to this learning model, learning that takes place more effectively because it combines the three learning styles, applying this model while providing direct experience. Therefore, the VAK learning model was tried out with diorama learning media.

Media is a tool that functions as an intermediary for delivering information (Hariati, 2019). Diorama media are stated as media that are classified as three-dimensional media whose size can be adjusted to the situation in the classroom (Ayogas, 2019). (Amalia, 2017) argues that dioramas are used to explain or to demonstrate a situation. Dioramas are useful in conveying information about events in the past. Even diorama media can also be used as a medium that describes the future (Lestari, 2015). Diorama media can be provided in the form of information that can make it easier to understand the media, but also pay attention to its meaning and according to needs. Diorama media can be used by teachers anywhere because this media is not permanently created media, media can be moved outside the classroom, or in the middle of the class. So that if the media is used properly it can be used in the next class or the same material is obtained by other classes. Making media also does not require a lot of money because it uses unused materials, such as newspapers, cardboard, paper, plastic and so on. The media must be following what will be discussed, so it is necessary to pay attention to the design that is designed so that later there will be no misinterpretation or misinterpretation.

The advantage of diorama media is that the design used in designing the media is very attractive because it is a replica of the original object. (Novelinda, 2017) states that in making this media, objects and plants can be used around. Media diorama is one of the replica media so that it can attract the attention of people and even students. By using the VAK Model, which helps with diorama media, it is hoped that learning will become more meaningful.

Based on the descriptions that have been presented, several relevant research results strengthen that the VAK model assisted by diorama media has a positive influence on the learning implementation process so that it has an influence on students' knowledge competencies: 1). (Dwitayanti, 2013) states that the VAK learning model has a better effect than conventional learning. 
This study has a difference, the media used. 2). (Parwati, 2018) states that there is a significant effect on the VAK learning model providing a school environment has a positive impact on science learning outcomes. The differences in this study are the media used and the dependent variable. 3). (Arisanti, 2013) states that the quantum learning model type VAK (Visual Auditory Kinesthetic) has a better effect on science learning outcomes.

From this description, it is necessary to carry out research to increase students' knowledge of social and cultural studies. By applying the Visualization, Auditory, Kinesthetic (VAK) learning model, it is hoped that it can improve the competence of students' knowledge, especially the content of social studies material. So, the learning model was tried out with the title "The Effect of Visualization, Auditory, Kinesthetic (VAK) Learning Model Assisted by Diorama Media on Social Science Competency for Fourth Grade Students of Elementary School in Gugus Letda Kajeng Academic Year 2019/2020". Based on this explanation, this study aims to determine the significant effect of the Visualization, Auditory, Kinesthetic (VAK) learning model assisted by diorama media on the competence of social science knowledge for fourth-grade students of Elementary School in Gugus Letda Kajeng for the 2019/2020 academic year. This research is different from research that has been carried out by other researchers, there are innovations in the media used, the diorama media. By applying the model and learning media, it is hoped that the research carried out can help the problems found in Elementary School in Gugus Letda Kajeng.

\section{Research Method}

The type of research used is quantitative research with experimental design, quasiexperimental (Quasi-Experiment). This design has an experimental group as well as a control group. In the implementation of research, there will be external variables that might affect the implementation of the research and this research cannot control these outside variables (Sugiyono, 2016). This is due to the ability to pay attention to the character and behavior of very exclusive students. This research also does not have mastery in understanding students' understanding of the treatment being carried out. The use of "Nonequivalent control group design" as the design of this study.

According to (Sugiyono, 2016) Population is a subject that has been decided by the researcher to be the object of research and then observed, studied, and got a conclusion. The population is a subject that has been decided by the researcher to be the object of research and then observed, studied, and obtained a conclusion (Sugiyono, 2016) The population used is all fourth-grade students of Elementary School in Gugus Letda Kajeng for the 2019/2020 academic year. Determination of the sample using a random sampling technique. When using this technique, the specified class will be randomized. Every student who enters the population all has the same opportunity when randomized to get a sample and be used as an object of research. Because the classes in Elementary School in Gugus Letda Kajeng have been formed and cannot be changed, so the classes that have been selected are left as they are. Therefore, the selected class has no interference or individual randomization which will have an impact on the situation and condition of students who will later find out that they are directly involved in a study, so that it can be minimized and run properly and show the effect of the treatment has been given.

Based on the draw that has been carried out, there are 2 classes selected to be the sample. Grade four B Elementary School of 4 Pemecutan which had 38 students appeared first in the lottery, while grade four Elementary School of 8 Pemecutan which had 36 students appeared in the second lottery. The two classes that have been selected are given a pretest to find out whether the class is equal or not. To determine the equivalent class using the t-test. Before using the t-test, the normality and homogeneity tests were carried out. After the pretest was tested for equality and it was declared equal, the drawing was carried out again on two samples to determine the experimental group and the control group and the class $4 \mathrm{~B}$ was selected as the experimental group and given treatment in the form of RPP with the VAK learning model assisted by diorama media and class 4B The dismissal was chosen as the control group given conventional learning.

The data collection method in this research is using the test method. The test is a tool used to measure. These measurements are following the desired objectives by following the existing regulations. In conducting research, the test method is given to samples both individually and in groups by answering several questions. The answers from each sample will get their respective scores. This regular multiple-choice test has 4 answer choices (a, b, c or d) with a total number of questions is 50 items. Each question gets a score of 1 if the question is answered correctly (according to the answer key), while if the question is answered incorrectly, it will get a score of 0.50 questions 
that have been made contain an identifier based on the social studies cognitive competence, C1-C4. The preparation of tests is based on Basic Competencies following the material provided at the time of treatment. The basic competencies and indicators used when preparing the research instrument.

Table 2. Preparation of Basic Competencies and Indicators for Social Science Competency Instruments

\begin{tabular}{|c|c|c|}
\hline Basic Competencies & Indicator & Cognitive type \\
\hline \multirow{6}{*}{$\begin{array}{l}\text { Identifying social, } \\
\text { economic, cultural, ethnic } \\
\text { and religious diversity in } \\
\text { the local province as the } \\
\text { identity of the Indonesian } \\
\text { nation and its } \\
\text { relationship to spatial } \\
\text { characteristics. }\end{array}$} & $\begin{array}{l}\text { 3.1.1 Explaining the relationship between the } \\
\text { number of ethnic groups and the } \\
\text { conditions of the region in Indonesia }\end{array}$ & $\mathrm{C} 2$ \\
\hline & $\begin{array}{l}\text { 3.1.2 Identifying the diversity of non- } \\
\text { agricultural economic activities } 3.1 .3 \\
\text { Identifying the diversity of agricultural } \\
\text { economic activities }\end{array}$ & $\mathrm{C} 4$ \\
\hline & $\begin{array}{l}\text { 3.1.4 State the tribe in the local provision as the } \\
\text { identity of the Indonesian nation }\end{array}$ & $\mathrm{C} 4$ \\
\hline & $\begin{array}{l}\text { 3.1.5 Mentioning the uniqueness of the } \\
\text { traditional house as the identity of the } \\
\text { Indonesian nation }\end{array}$ & C1 \\
\hline & $\begin{array}{l}\text { 3.1.6 State the uniqueness of traditional } \\
\text { clothing as the identity of the Indonesian } \\
\text { nation }\end{array}$ & C1 \\
\hline & $\begin{array}{l}\text { 3.1.1 Explaining the relationship between } \\
\text { the number of ethnic groups and the } \\
\text { conditions of the region in Indonesia }\end{array}$ & C1 \\
\hline
\end{tabular}

After the preparation of the questions is complete, proceed with testing the instrument. Testing research instruments is something that affects the implementation of research which includes validity testing, then the next step is to test the difference power, difficulty level, and finally reliability. Content validity is the suitability of the content of the questions concerned with the objectives and material. The content validity test is curriculum and grid. Of the 50 items that have passed the validity test, there are 35 valid questions. Then the question is tested for different power and gets 5 items with bad criteria, then the question is discarded. The 30 items were then tested for the level of difficulty and reliability so that the 30 items were declared reliable. Based on this, the questions used in this study have been validated and declared reliable.

The method of data analysis in this study uses inferential statistics with the t-test technique which aims to test the hypothesis. Before the analysis is done, the prerequisite test is conducted first, the normality test of the data distribution using the Kolmogorov-Smirnov test and the variance homogeneity test using the $\mathrm{F}$ test (Fisher).

\section{Result and Discussion}

The data obtained in this study were the posttest data on the competence of social science knowledge for fourth-grade students who followed the Visualization, Auditory, Kinesthetic (VAK) learning model assisted by diorama media and students who took conventional learning. Based on this, the data in this study can be divided into two groups: 1). Experimental group social science knowledge competency data. 2) Data of the control group's social science knowledge competency. Based on the data obtained in the experimental group IVB students, 35 students obtained the same score or more than KKM 70 with a percentage of $87 \%$ having reached the KKM. Whereas in the fourth-grade students of the control group, 15 students obtained the same score or more than KKM 70 with a percentage of $40.4 \%$.

After obtaining the data on each sample, then the prerequisite test is carried out which includes the normality test and the homogeneity test. The purpose of using the normality test is to determine the distribution of the frequency values used to test the competence data of students' social studies knowledge in both samples using the Kolmogorov-Smirnov formula. The criteria for carrying out tests on the normality test are the significance of the test on the Dhitung compared to the Kolmogorov-Smirnov Dtable value. If the value of Dhitung $<$ Dtabel Kolmogorov-Smirnov and a

Ni Luh Komang Widya Santhi ${ }^{1}$, I.G.A Agung Sri Asri' ${ }^{2}$, I.B. Surya Manuaba ${ }^{3}$ Social Studies Learning With Visualization, Auditory, Kinesthetic (VAK) Learning Model Assisted by Diorama Media Increases Student Knowledge Competence 
significance level of 5\%, then the distribution of sample data is normally distributed. The following is a recapitulation of the normality test results for both samples.

Table 3. Results of Normality Test for Experiment Group and Control Group

\begin{tabular}{cccccc}
\hline No & Sample & Total Sample & Dhitung $^{\text {Dabel Kolmogorov }}$ & $\begin{array}{c}\text { Deterangan } \\
\text { Smirnov score }\end{array}$ & Ketronal \\
\hline 1 & Experiment & 39 & 0,106 & 0,210 & $\begin{array}{c}\text { Normatribution } \\
\text { distribal } \\
\text { distribution }\end{array}$ \\
\hline
\end{tabular}

Based on the results of the analysis in the experimental group, the value of Dhitung $=0.106$ and Dtabel Kolmogorov-Smirnov $=0.210$. It states that Dhitung $=0.106<$ Dtabel $=0.210$ KolmogorovSmirnov, it can be stated that the results of the Social Science Competency of the experimental group are normally distributed. While the control group, with the value of Dhitung is 0.173 and Dtabel Kolmogorov-Smirnov $=0.210$. This shows that Dhitung $=0.102<$ Dtabel $=0.210$ KolmogorovSmirnov, it can be stated that the results of the Social Science Competency of the control group are normally distributed.

Furthermore, the homogeneity test was carried out based on the social science knowledge competency data that had been obtained in the two samples. The homogeneity test aims to prove the differences stated in the hypothesis test that there is a difference, this happens because of differences in variance in each group from the homogeneity test, the difference does not occur because of differences between groups. The homogeneity test of variance in this study used the $\mathrm{F}$ test. The following is a recapitulation of the homogeneity test for both samples.

Tabel 4. Research Sample Homogeneity Test Results

\begin{tabular}{cccccccc}
\hline No & Group & $\mathbf{S}^{\mathbf{}^{2}}$ & $\mathbf{S}_{\mathbf{2}}{ }^{\mathbf{2}}$ & $\mathbf{d k}$ & $\mathbf{F}_{\text {hitung }}$ & $\mathbf{F}_{\text {tabel }}$ & Information \\
\hline 1 & Experiment & 115,279 & & 38 & 1,323 & $\begin{array}{c}1,73 \\
4\end{array}$ & Homogen \\
\hline & Control & & 152,494 & 36 & & 4 & \\
\hline
\end{tabular}

With a significance level of $5 \%$ and having degrees of freedom ( $\mathrm{dk}$ ) for the $\mathrm{n} 1-1$ numerator (39 - $1=38)$ and the denominator $n 2-1(37-1=36)$, it is obtained Ftable $=1.734$ and Fcount $=1.323$. This means that Fcount $=1.323<$ Ftable $=1.734$, so the data for the two groups has a homogeneous variance.

After the data is normally distributed and homogeneous, then the hypothesis is tested using the t-test technique. Hypothesis testing criteria, if tcount $\leq$ ttable, then Ho is accepted and Ha is rejected. Meanwhile, if tcount $>$ ttable then $\mathrm{HO}$ is rejected and $\mathrm{Ha}$ is accepted. With a significant level of $5 \%$ with $\mathrm{dk}=\mathrm{n} 1+\mathrm{n} 2-2$. The t test with the polled variance formula was used to test the hypothesis of this study. The following is a recapitulation of hypothesis testing.

Table 5. Research Sample Hypothesis Test Results

\begin{tabular}{ccccccccc}
\hline No & Sample & Average & Variance & $\mathbf{d k}$ & $\mathbf{N}$ & $\mathbf{t}_{\text {hitung }}$ & $\mathbf{t}_{\text {tabel }}$ & Conclusion \\
\hline 1 & Experiment class & 82,190 & 115,279 & & 39 & \multirow{2}{*}{6,726} & \multirow{2}{*}{1,993} & $\mathrm{H}_{0}$ rejected \\
2 & Control class & 61,169 & 152,494 & & 37 & & & \\
\hline
\end{tabular}

Based on the results of the $t$ test calculation, the results obtained tcount $=6.726$ with a significance level of $5 \%$ and $\mathrm{dk}=\mathrm{n} 1+\mathrm{n} 2-2=39+37-2=74$ indicating the value of $\mathrm{t}$ table $=1.993$. Thus, it is obtained that tcount $=6.726>$ ttable $=1.993$. H0 which reads that there is no significant difference in Social Science Knowledge Competence between the groups that were taught with the Visualization, Auditory, Kinesthetic (VAK) learning model assisted by diorama media and the group that was given conventional learning in the fourth grade of Elementary School Gugus Letda Kajeng VI Academic Year 2019/2020 was rejected. In addition, the average value of each group shows the experimental group $=82.190>=64.476$ control group. The difference in the average value obtained by the experimental class, the fourth grade Elementary School of 4 Pemecutan which is far from the 
control group, the fourth grade of Elementary School 8 Pemecutan, which shows that the treatment using the VAK learning model assisted by diorama media affects the posttest results of the students' social science competency knowledge experimental class. The difference between the two samples is influenced by the following factors.

First, the VAK learning model has an impact on the competence of social studies knowledge because it can increase student activeness, work in groups, and can express opinions freely. According to (Saputra, 2014), the VAK model can use the potential contained in oneself without any obstacles so that an active learning atmosphere grows and provides meaning in learning. During this process, students work together between groups to collect information from the media that has been provided. This is in line with (Shoimin, 2014) VAK is three modalities known as learning styles. Learning style is a process where a person can absorb sound, objects, objects, or other things, then organize and then process them so that they become information. (Rukmana, 2018) states that the VAK model provides opportunities for students to take advantage of their respective learning styles. (Pebriani, 2013) argues that by using a learning style, learning that takes place becomes more effective, so that students can understand the material. Learning feels more fun and students are active when learning begins because all students try to find information without any restrictions either by discussing with the group or with the media that has been provided, so there will be no less conducive atmosphere due to boredom. Providing direct experience because in its implementation students are led to seek information independently, both using physical activities such as carrying out demonstrations in front of the class, observation, and active discussions with group friends (Pratama, 2017). It increases student activity because the model uses three learning styles, so that no student is bored with listening to the material or is bored if learning takes place by reading and answering only questions, because utilizing the three modalities is the same as fostering student activity. Treatment using the VAK model involves children in four stages, the first is the preparation stage. The preparation stage is very important for teachers and students because if students are not ready to receive material or learning knowledge, they will not be able to run conducive, such as dirty classes, students are still noisy or other problems. So that this stage requires collaboration between students and teachers and at the time of carrying out the research it went well so that the teacher continued the next stage. The second stage is the delivery stage which aims to find new knowledge which of course uses each learning style, either by reading books, listening to teacher explanations, opinions from friends to discussing. After students pass this stage, the teacher provides learning media that serves to facilitate students in understanding the material. According to (Sudiantini, 2019) when students pass through these stages students are directly involved maximally in finding and understanding a concept through physical activities, including demonstrations, observations, and active discussions. From these stages the learning process that takes place becomes more active, students can work together in groups and students can explore their knowledge with existing potential.

Second, because of the use of the media used, diorama media. Diorama media can have a positive influence on the learning process in the classroom because diorama media can attract students' attention so that students focus on the media provided by the teacher. Learning that is initially passive becomes active because student learning resources are presented in attractive media. This is in line with (Hidayati, 2017). Diorama media is a three-dimensional or miniature media of the original object made using simple materials, either from used materials or materials from the surrounding environment. Diorama media can represent three children's learning styles, so that learning takes place actively and pleasantly. (Marini, 2017) states that diorama media is not only a mediator for teachers to students, but also helps students train their potential. The use of diorama media can focus their attention so that students will use their respective potential. After receiving the information, each group has its responsibilities, so that no member is passive. Media dioramas contain information in helping students gain knowledge so that students actively explore their knowledge. The diorama media can motivate students or users to get a more appreciative experience. Diorama media provide replicas of real objects as well as help teachers to show events, as well as objects that cannot be brought directly. According to (Hidayati, 2017), The existence of replica media fosters interest and a sense of wanting to learn because it is facilitated by attractive media so that students' motivation in learning increases and learning takes place more concretely. At the end of the third stage, the teacher gives a question in the form of a quiz. The quiz is not included in the stages, however, the purpose of holding it is to find out the knowledge that students get. The quizzes are given in the form of questions based on the material that students get, especially the material that comes from the media provided. Each group gets points if they answer correctly, so group members 
work together to get a lot of points for their group. Finally, the delivery of results, these results are information or answers that they have discussed with the group and each group delivers the results. This stage aims to strengthen knowledge. Students conclude the material they have obtained, if there are still some incorrect opinions, the teacher's role is very important at this stage so that there is no misperception of the knowledge they have acquired. So that the material and knowledge they get has been confirmed by the teacher with the end getting a conclusion and each student's answer is given reinforcement by the teacher so that students during the next lesson do not feel embarrassed if the answers they have presented are not correct. This results in the competence of social studies knowledge.

Third, the combination of the VAK model with diorama media has a positive impact on students because the stages that are passed and the media used by students can work together in groups. Competing with other groups. According to (Nurkamaliah, 2018), The use of this media raises curiosity about the material to be studied because of its interesting shape, so that students are interested in using it in the learning process. This influences the competence of students' social studies knowledge.

Based on observations, the treatment of the two samples is very different. First, during the implementation process of learning the teacher dominates the learning activities so that learning is only teacher-centered. Second, this learning has an impact, students are more passive because learning only comes from the teacher. Such learning does not provide new experiences and challenges for students, there is no media that facilitates it also affects learning so students feel bored quickly. In the end, it will result in student learning outcomes to be less than optimal.

The results of this study are also reinforced by research conducted by (Purwandari, 2014) which states that the VAK-Nuanced Experiential Learning model (Visual, Auditory, Kinesthetic) affects the fifth-grade science learning outcomes of the Class Five Elementary School Letkol Wisnu. (Partiani, 2014) in his research states that the application of the Brain-Based Learning model with visual, auditory, kinesthetic (VAK) nuances affects the science learning outcomes of fifth-grade students of Elementary School in Gugus IV, Sukawati Regency, 2013/2014 academic year. (Widiartha, 2018) states that the Visualization Auditory Kinesthetic Learning model assisted by Interactive Multimedia affects the competence of scientific knowledge of fifth-grade students at Elementary School in Gugus Dewi Sartika in the 2017/2018 academic year.

Based on this explanation, it can be stated that the Visualization, Auditory, Kinesthetic (VAK) learning model assisted by diorama media has an effect on the social science competency knowledge of fourth-grade students of Elementary School in Gugus Letda Kajeng for the 2019/2020 academic year.

\section{Conclusion}

Based on the results of data analysis it can be concluded that the Visualization, Auditory, Kinesthetic (VAK) learning model assisted by diorama media has an effect on the social science competence of fourth grade students of Elementary School in Gugus Letda Kajeng for the 2019/2020 academic year. Based on the conclusions, there are several suggestions given from the research that has been carried out, namely that teachers are advised to improve the atmosphere or learning process so that it becomes active again either by using an appropriate model such as the VAK learning model or using media, thereby increasing the knowledge competence of students. To the principal, the results of this study can be used to support teachers in improving the quality of the implementation of learning. Apart from that, completing the facilities and infrastructure also needs to be improved because it will affect the learning implementation process. So as to produce students who have quality output. To other researchers, it is hoped that this research will be used as reference material in the implementation of subsequent research so that they will get more diverse topics and are expected to be able to find innovations in the learning implementation.

\section{References}

Adnyani, N. L. S. (2014). Pengaruh Model VAK Berbantuan Lingkungan Terhadap Hasil Belajar IPA Siswa Kelas V SD Gugus Mas. MIMBAR PGSD Undiksha, 2(1). http://dx.doi.org/10.23887/ijpgsd.v2i1.3593

Agung, A. A. G. (2014). Metodologi Penelitian Pendidikan. Aditya Media Publishing. 
Alditia, A. Y. T. (2016). Pengaruh Model Visual, Auditory, Dan Kinesthetic (VAK) Terhadap Hasil Belajar Siswa Pada Materi Sifat-Sifat Cahaya. Jurnal Pena Ilmiah, 1(1). https://doi.org/10.23819/pi.v1i1.3041

Amalia, M. D. (2017). Pengembangan Media Diorama Pada Pembelajaran Tematik Terintegrasi Tema Indahnya Negeriku Untuk Meningkatkan Hasil Belajar Siswa. Jurnal Penelitian Pendidikan, 20(2). https://doi.org/10.20961/paedagogia.v20i2.9850

Ariastini, N. L. P. (2013). Pengaruh Model Pembelajaran Kuantum Tipe VAK (Visual Audiotory Kinesthetic) Siswa Kelas V SD Negeri 2 Sesetan. MIMBAR PGSD Undiksha, 1(1). http://dx.doi.org/10.23887/jijpgsd.v1i1.1185

Ayogas, Y. F. (2019). 2017/2018, Pengembangan Media Diorama Pada Tema Daerah Tempat Tinggalku Sub Tema Lingkungan Tempat Tinggalku Terhadap Hasil Belajar Siswa Kelas IV SDN II Sambitan Tahun Ajaran. Jurnal Pendidikan Dan Pembelajaran Anak Sekolah Dasar, 4(2). http://dx.doi.org/10.29100/jpsd.v4i02.1388

Dwitayanti, N. M. D. (2013). Model Pembelajaran VAK Berbantuan Media VCD Berpengaruh Terhadap Prestasi Belajar Matematika Siswa Kelas IV SD Gugus V Dr. Soetomo. MIMBAR PGSD Undiksha, 1(1). http://dx.doi.org/10.23887/jijpgsd.v1i1.1316

Elisa, T. D. (2019). Penerapan Model Pembelajaran VAK (Visualization, Auditory, Dan Kinestethic) Terhadap Hasil Belajar IPA Peserta Didik Kelas IV SD Negeri 147 Pekanbaru. Jurnal Dinamika Pendidikan Dasar, 11(1), 19-26. DOI: 10.30595/dinamika.v11i1.5981

Hariati, F. (2019). Penggunaan Media Diorama Untuk Meningkatkan Hasil Belajar IPS Tema Udara Bersih Bagi Kesehatan Pada Siswa Kelas V B Di SDN Menanggal - Mojokerto. Jurnal Penelitian Pendidikan Guru Sekolah Dasar, 7(7), 3861-3875. https://jurnalmahasiswa.unesa.ac.id/index.php/jurnal-penelitian-pgsd/article/view/32014

Hidayati, A. N. (2017). Pengaruh Penggunaan Media Diorama terhadap Hasil Belajar Siswa pada Materi Kegiatan Ekonomi. Jurnal Ilmiah Pendidikan Guru Sekolah Dasar, 4(1). https://ejournal.upi.edu/index.php/pedadidaktika/article/view/7417

Lestari, T. (2015). Pengaruh Penggunaan Media Diorama Terhadap Hasil Belajar Siswa Kelas V Pada Tema Ekosistem di Sekolah Dasar. JPGSD, 3(2). https://www.neliti.com/publications/253944/pengaruh-penggunaan-media-dioramaterhadap-hasil-belajar-siswa-kelas-v-pada-tema

Marini, S. (2017). Pengaruh Model Problem Based Learning Berbantuan Media Diorama Terhadap Keterampilan Menulis Teks Diskusi Siswa Kelas VIII MTs Negeri Muara Bungo. Jurnal Pendidikan Bahasa Indonesia, 6(2). https://doi.org/10.24036/8655-019883

Novelinda, P. I. K. (2017). Pengaruh Model Pembelajaran Talking Stick Berbantuan Media Diorama Terhadap Hasil Belajar IPA Siswa Kelas V. MIMBAR PGSD Undiksha, 5(2). http://dx.doi.org/10.23887/jijggsd.v5i2.11021

Nurellah, A. (2016). Penerapan Model Pembelajaran Visual, Auditorial, Dan Kinestetik Untuk Meningkatkan Hasil Belajar Siswa Sekolah Dasar. Jurnal Pena Ilmiah, 1(1). https://doi.org/10.23819/pi.v1i1.3053

Nurkamaliah, A. (2018). Pengaruh Model Pembelajaran Mind Mapping Berbantu Media Diorama Terhadap Hasil Belajar Siswa Pembelajaran Tematik Kelas IV SD Muhamadiyah 01 Pekalongan. Jurnal Guru Kita (JGK), 2(3), 65-73. https://doi.org/10.24114/jgk.v2i3.10385

Parbawa, I. G. N. M. A. (2018). Pengaruh Model Pembelajaran Visual Auditory Kinestetik Dan Motivasi Belajar Terhadap Kompetensi Pengetahuan IPS Siswa Kelas IV. Jurnal Ilmiah Sekolah Dasar, 2(1). http://dx.doi.org/10.23887/jisd.v2i1.13896

Partiani, N. K. A. Y. (2014). Model Brain Based Learning Bernuansa Visual, Auditori, Kinestetik (VAK) Berpengaruh Terhadap Hasil Belajar IPA Kelas V. MIMBAR PGSD Undiksha, 2(1). http://dx.doi.org/10.23887/ijpgsd.v2i1.3012

Parwati, I. A. K. C. (2018). Pengaruh Model Pembelajaran VAK (Visual, Auditorial, Kinestetik) Bermediakan Lingkungan Sekolah Terhadap Hasil Belajar IPA. Jurnal Pendagogi Dan Pembelajaran, 1(3). http://dx.doi.org/10.23887/ip2.v1i3.19342 
Pebriani, N. P. A. (2013). Pengaruh Model Pembelajaran Quantum Tipe VAK Berbantuan Media Magic Box Terhadap Hasil Belajar IPA Kelas IV SD. MIMBAR PGSD Undiksha, 1(1). http://dx.doi.org/10.23887/jjpgsd.v1i1.730

Pratama, I. W. A. (2017). Pengembangan Multimedia Interaktif Berbasis Model VAK Pada Mata Pelajaran IPA Siswa Kelas V Di SDN 2 Banjar Bali. Jurnal EDUTECH, 5(1), 132-141. http://dx.doi.org/10.23887/jeu.v5i1.20635

Pratiwi, N. P. S. (2014). Pengaruh Model Brain-Based Learning Berbantuan Media Diorama Terhadap Hasil Belajar IPS Siswa Kelas V SD Gugus VIII Sukawati Tahun Ajaran 2013/ 2014. MIMBAR PGSD Undiksha, 2(1). http://dx.doi.org/10.23887/jjpgsd.v2i1.2279

Purwandari, N. M. A. (2014). Model Experiential Learning Bernuansa VAK (Visual, Auditori, Kinestetik) Berpengaruh Terhadap Hasil Belajar IPA Kelas V SD Gugus Letkol Wisnu. MIMBAR PGSD Undiksha, 4(1). http://dx.doi.org/10.23887/jjpgsd.v2i1.3007

Rukmana, W. (2018). Peningkatan Aktivitas dan Hasil Belajar dengan Model Pembelajaran VAK Berbantuan Media Tongkat Tokoh. International Journal of Elementary Education, 2(3), 156164. http://dx.doi.org/10.23887/ijee.v2i3.15954

Sakti, R. A. E. (2019). Penerapan Model VAK Berbasis HOTS Untuk Meningkatkan Hasil Belajar Siswa $\begin{array}{lllllll}\text { Kelas } & 1 & \text { SD. HOLISTIKA Jurnal Ilmiah }\end{array}$ https://jurnal.umj.ac.id/index.php/holistika/article/view/5343

Saputra, A. B. (2014). Implementasi Model Pembelajaran VAK Berbantuan Media Audio Visual Untuk Meningkatkan Hasil Belajar IPA Siswa Kelas IVB SD No. 2 Banyuasri. MIMBAR PGSD Undiksha, 2(1). http://dx.doi.org/10.23887/ijpgsd.v2i1.2640

Sari, A. K. (2014). Analisis Karakteristik Gaya Belajar VAK(Visual, Auditorial, Kinestetik)Mahasiswa Pendidikan Informatika Angkatan 2014. Jurnal Ilmiah Edutic, 1(1). https://doi.org/10.21107/edutic.v1i1.395

Setiawan, A. (2019). Pengaruh Model Pembelajaran Visual Auditory Kinesthetic (VAK) Terhadap Keaktifan Siswa. Profesi Pendidikan Dasar, 1(1), 81-90. https://doi.org/10.23917/ppd.v1i1.7284

Sudiantini, N. P. A. (2019). Pengaruh Model Pembelajaran Visualization, Auditory, Kinesthetic (VAK) Berbasis Tri Hita Karana terhadap Kompetensi Pengetahuan PKn. Jurnal Penelitian Dan Pengembangan Pendidikan, 3(3). http://dx.doi.org/10.23887/jppp.v3i3.18159

Sugiyono. (2016). Metode Penelitian kuantitatif, kualitatif, dan R\&D (Bentang Pustaka, Ed.).

Suryantini, N. W. N. (2017). Pengaruh Model Pembelajaran Visual Auditori Kinestetik Berbantuan Audio Visual Terhadap Kompetensi Pengetahuan IPA Kelas V. MIMBAR PGSD Undiksha, 5(2). http://dx.doi.org/10.23887/jipgsd.v5i2.10636

Trianto. (2012). Model Pembelajaran Terpadu. Bumi Aksara.

Wahyuni, N. W. (2020). Pengaruh Model Visualization, Auditory, Kinestetic (VAK) Berbantuan Media Gambar Terhadap Hasil Belajar IPA. International Journal of Elementary Education, 4(1). http://dx.doi.org/10.23887/ijee.v4i1.24328

Widiartha, K. D. . (2018). Pengaruh Model Pembelajaran Visualization Auditory Kinestetic Berbantuan Mutimedia Interaktif Terhadap Kompetensi Pengetahuan IPA. Jurnal Penelitian Dan Pengembangan Pendidikan, 2(2), 145-151. http://dx.doi.org/10.23887/jppp.v2i2.15396 